\title{
MODEL SISTEM INFORMASI MONITORING PERKULIAHAN FAKULTAS TEKNIK UNIVERSITAS SEMARANG BERBASIS WEB
}

\author{
Derman, S.T, M.T ${ }^{1)}$,Harmini, ST.,M.Eng') \\ ${ }^{1,2}$ Jurusan Teknik Elektro Fakultas Teknik Universitas Semarang. \\ Jl. Soekarno-Hatta, Tlogosari Semarang \\ Email: derman@usm.ac.id, harmini@usm.ac.id
}

\begin{abstract}
Abstrak - Perkembangan Teknologi Informasi yang semakin maju menuntut Perguruan Tinggi untuk memberikan Informasi yang cepat guna memenuhi kebutuhan Informasi dan Monitoring perkuliahan bagi Dosen, Mahasiswa dan staf Admin. Penelitian ini bertujuan untuk merancang suatu Model Sistem Informasi dan Monitoring Perkuliahan (SIMP) pada Fakultas Teknik Universitas Semarang berbasis Web. Cakupannya meliputi perencanaan perkuliahan, pelaksanaan perkuliahan, evaluasi pelaksanaan perkuliahan, pengendalian pelaksanaan perkuliahan dan perbaikan perencanaan perkuliahan. Penelitian ini menghasilkan suatu aplikasi model Sistem Informasi dan Monitoring perkuliahan yang bertujuan untuk memudahkan dan mempercepat penyusunan waktu, ruangan dan jadwal mata kuliah serta kemudahan dalam monitoring status kehadiran dosen dikelas baik kepada mahasiswa ataupun pihak lain secara real time tanpa harus datang ke kampus mengecek papan informasi. Kontribusi hasil penelitian ini akan sangat berdampak terhadap penerapan Ipteks bagi institusi Perguruan Tinggi serta untuk mewujudkan pengembangan Fakultas Teknik Universitas Semarang sebagai Fakultas unggulan pada tahun 2023. Metode yang digunakan adalah metode dynamic priorities yang mendahulukan proses yang memiliki prioritas tertinggi serta mampu menanggapi perubahan lingkungan sistem saat beroperasi. Pemodelan sistem menggunakan paket XAMPP yang didalamnya terintegrasi modul MySQL untuk keperluan basis data, PHP untuk pengelolaan sistem informasi, dan Apache untuk keperluan simulasi. Hasil Penelitian menunjukan implementasi dari aplikasi Model Sistem Informasi Monitoring Perkuliahan Fakultas Teknik Universitas Semarang berjalan dengan baik
\end{abstract}

Kata Kunci: Monitoring, Universitas Semarang, Web.

Abstract - The development of Information Technology is increasingly demanding that Higher Education to provide information quickly to meet the needs of Information and Monitoring Course for Lecturers, Students and Admin staff. This study aims to design a Model Information System and Monitoring Course at the Faculty of Engineering, University of Semarang Web-based. Coverage includes lecture planning, lecturing, evaluation of lecturing, control of lecturing and improvement of lecture planning. This research produces an application of Information System and Monitoring model of lecturing which aims to facilitate and accelerate the preparation of time, room and course schedule and ease in monitoring the attendance status of lecturers in class either to students or other parties in real time without having to come to campus check board information. The contribution of this research results will greatly affect the application of science and technology for higher education institutions and to realize the development of Faculty of Engineering Semarang University as a leading Faculty in 2023. The method used is dynamic priorities method which prioritizes the process that has the highest priority and is able to respond to changes in the system environment operate. Modeling the system using XAMPP package in which integrated MySQL module for database purposes, PHP for management of information systems, and Apache for simulation purposes. The results showed the implementation of the application of Information Systems Monitoring System Lectures Faculty of Engineering, University of Semarang goes well.

Keywords: Monitoring, Semarang University, Web.

\section{PENDAhULUAN}

\subsection{Latar Belakang}

Perkembangan Teknologi Informasi yang semakin maju menuntut Universitas dan Perguruan Tinggi untuk memberikan Informasi yang cepat. Meski teknologi informasi telah berkembang pesat, namun di Fakultas Teknik Universitas Semarang belum banyak menerapkan Teknologi Informasi untuk mendukung kegiatan akademik. Misalnya Informasi dan Monitoring perkuliahan yang masih menggunakan cara-cara manual. Padahal di era Teknologi Informasi seperti saat ini, Universitas di tuntut kecepatan dalam memberikan informasi guna memenuhi kebutuhan Dosen, Mahasiswa serta staf Akademiknya. Dalam penyusunan jadwal perkuliahan di Fakultas Teknik Universitas Semarang memang tidak mudah. Staf admin bagian akademik harus mencocokan jumlah mahasiswa yang ada dalam daftar hadir mata kuliah dengan ruangan yang ada disesuaikan dengan kapasitas daya tampung ruangan. Daya tampung ruangan ini jumlahnya bervariasi, ada ruangan yang berkapasitas 25 orang, 40 orang, 50 orang, 60 orang dan 80 orang. Namun di dalam pelaksanaannya terkadang jumlah mahasiswa dan daya tampung ruangan tidak sesuai sehingga Dosen yang akan memberikan kuliah harus bertukar ruangan dengan dosen lainnya. Masalah ini sering terjadi di minggu pertama awal perkuliahan.

Masalah tidak terbatas pada ruangan saja. Masalah yang lain juga muncul saat mahasiswa yang membutuhkan informasi akademik harus datang ke kampus untuk melihat papan pengumuman yang memampangkan informasi dan jadwal perkuliahan. Untuk urusan kehadiran Dosen yang pada hari itu mengajar juga tidak diketahui oleh mahasiswa. Banyak mahasiswa kemudian datang ke ruang informasi menemui staf admin untuk menanyakan status kehadiran Dosennya. Namun staf admin tidak bisa memberikan jawaban tentang status kehadiran Dosen yang bersangkutan. Tidak 
adanya informasi Dosen menimbulkan ketidakpastian dan tentunya kerugian bagi Mahasiswa yang sudah datang kekampus. Masalah ini sebenarnya bisa diantisipasi sejak awal jika ada suatu aplikasi yang bisa diakses dengan mudah secara real time oleh mahasiswa untuk mengetahui status kehadiran Dosen, ruangan dan waktu perkuliahannya.Oleh karena itu, untuk menjembatani, mempermudah dan mempercepat penyusunan jadwal kuliah serta informasi status kehadiran dosen baik kepada mahasiswa ataupun pihak lain tanpa harus datang mengecek ke papan informasi dan bertanya kepada staf admin diperlukan suatu model aplikasi Sistem Informasi Monitoring Perkuliahan berbasis Web yang dapat diakses langsung oleh mahasiswa kapanpun dan dimanapun. Serta dalam rangka mengembangan Fakultas Teknik Universitas Semarang sebagai Fakultas unggulan pada tahun 2023, maka kebutuhan dari penerapan Sistem Informasi dan Monitoring aktifitas jadwal perkuliahan dengan didukung oleh penggunaan komponen teknologi informasi mutlak harus dilakukan.

\subsection{Perumusan Masalah}

Dari pemikiran tersebut, dirumuskan suatu permasalahan yaitu bagaimana merancang model aplikasi Sistem Informasi yang menyajikan informasi aktifitas perkuliahan secara real time pada Fakultas Teknik Universitas Semarang?

\subsection{Tujuan Penelitian}

Penelitian ini bertujuan untuk merancang model Sistem Informasi aktifitas perkuliahan pada Fakultas Teknik Universitas Semarang berbasis Web, yang cakupannya meliputi perencanaan perkuliahan, pelaksanaan perkuliahan, evaluasi pelaksanaan perkuliahan, pengendalian pelaksanaan perkuliahan dan perbaikan perencanaan perkuliahan.

\subsection{Luaran Penelitian}

Hasil akhir dari penelitian ini diharapkan dapat:

1. Menghasilkan prototype model aplikasi Sistem Informasi Monitoring Perkuliahan (SIMP) di Fakultas Teknik Universitas Semarang.

2. Dimuat dalam Jurnal Nasional Teknik Elektro dan Teknologi Informasi Terakreditasi

\subsection{Kontribusi Penelitian}

Kontribusi hasil penelitian ini akan berdampak terhadap:

1. Penerapan IPTEKS bagi institusi Perguruan Tinggi,

2. Mengembangkan Fakultas Teknik sebagai Fakultas unggulan pada tahun 2023, serta

3. Menjadi jawaban atas kebutuhan Informasi dan Monitoring bagi Dosen, Mahasiswa dan staf Admin.

\subsection{Latar Belakang}

Perkembangan Teknologi Informasi yang semakin maju menuntut Universitas dan Perguruan Tinggi untuk memberikan Informasi yang cepat. Meski teknologi informasi telah berkembang pesat, namun di Fakultas Teknik Universitas Semarang belum banyak menerapkan Teknologi Informasi untuk mendukung kegiatan akademik. Misalnya Informasi dan Monitoring perkuliahan yang masih menggunakan cara-cara manual. Padahal di era Teknologi Informasi seperti saat ini, Universitas di tuntut kecepatan dalam memberikan informasi guna memenuhi kebutuhan Dosen, Mahasiswa serta staf Akademiknya. Dalam penyusunan jadwal perkuliahan di Fakultas Teknik Universitas Semarang memang tidak mudah. Staf admin bagian akademik harus mencocokan jumlah mahasiswa yang ada dalam daftar hadir mata kuliah dengan ruangan yang ada disesuaikan dengan kapasitas daya tampung ruangan. Daya tampung ruangan ini jumlahnya bervariasi, ada ruangan yang berkapasitas 25 orang, 40 orang, 50 orang, 60 orang dan 80 orang. Namun di dalam pelaksanaannya terkadang jumlah mahasiswa dan daya tampung ruangan tidak sesuai sehingga Dosen yang akan memberikan kuliah harus bertukar ruangan dengan dosen lainnya. Masalah ini sering terjadi di minggu pertama awal perkuliahan.

Masalah tidak terbatas pada ruangan saja. Masalah yang lain juga muncul saat mahasiswa yang membutuhkan informasi akademik harus datang ke kampus untuk melihat papan pengumuman yang memampangkan informasi dan jadwal perkuliahan. Untuk urusan kehadiran Dosen yang pada hari itu mengajar juga tidak diketahui oleh mahasiswa. Banyak mahasiswa kemudian datang ke ruang informasi menemui staf admin untuk menanyakan status kehadiran Dosennya. Namun staf admin tidak bisa memberikan jawaban tentang status kehadiran Dosen yang bersangkutan. Tidak adanya informasi Dosen menimbulkan ketidakpastian dan tentunya kerugian bagi Mahasiswa yang sudah datang kekampus. Masalah ini sebenarnya bisa diantisipasi sejak awal jika ada suatu aplikasi yang bisa diakses dengan mudah secara real time oleh mahasiswa untuk mengetahui status kehadiran Dosen, ruangan dan waktu perkuliahannya.Oleh karena itu, untuk menjembatani, mempermudah dan mempercepat penyusunan jadwal kuliah serta informasi status kehadiran dosen baik kepada mahasiswa ataupun pihak lain tanpa harus datang mengecek ke papan informasi dan bertanya kepada staf admin diperlukan suatu model aplikasi Sistem Informasi Monitoring Perkuliahan berbasis Web yang dapat diakses langsung oleh mahasiswa kapanpun dan dimanapun. Serta dalam rangka mengembangan Fakultas Teknik Universitas Semarang sebagai Fakultas unggulan pada tahun 2023, maka kebutuhan dari penerapan Sistem Informasi dan Monitoring aktifitas jadwal perkuliahan dengan didukung oleh penggunaan komponen teknologi informasi mutlak harus dilakukan.

\subsection{Perumusan Masalah}

Dari pemikiran tersebut, dirumuskan suatu permasalahan yaitu bagaimana merancang model aplikasi Sistem Informasi yang menyajikan informasi aktifitas perkuliahan secara 
real time pada Fakultas Teknik Universitas Semarang?

\subsection{Tujuan Penelitian}

Penelitian ini bertujuan untuk merancang model Sistem Informasi aktifitas perkuliahan pada Fakultas Teknik Universitas Semarang berbasis Web, yang cakupannya meliputi perencanaan perkuliahan, pelaksanaan perkuliahan, evaluasi pelaksanaan perkuliahan, pengendalian pelaksanaan perkuliahan dan perbaikan perencanaan perkuliahan.

\subsection{Luaran Penelitian}

Hasil akhir dari penelitian ini diharapkan dapat:

3. Menghasilkan prototype model aplikasi Sistem Informasi Monitoring Perkuliahan (SIMP) di Fakultas Teknik Universitas Semarang.

4. Dimuat dalam Jurnal Nasional Teknik Elektro dan Teknologi Informasi Terakreditasi

\subsection{Kontribusi Penelitian}

Kontribusi hasil penelitian ini akan berdampak terhadap:

4. Penerapan IPTEKS bagi institusi Perguruan Tinggi,

5. Mengembangkan Fakultas Teknik sebagai Fakultas unggulan pada tahun 2023, serta

Menjadi jawaban atas kebutuhan Informasi dan Monitoring bagi Dosen, Mahasiswa dan staf Admin.

\section{KAJIAN LITERATUR}

2.1. Penelitian Terdahulu Tentang Sistem Penjadwalan Kuliah Sistem Informasi jadwal perkuliahan yang sudah dilakukan antara lain:

1. Elisa Usada Membuat rancang bangun Sistem Informasi jadwal perkuliahan berbasis jquery mobile dengan menggunakan PHP dan MySQL. Metode yang digunakan dalam rancang bangun aplikasi sistem informasi jadwal perkuliahan yaitu metode waterfall. Pengujian aplikasi sistem informasi jadwal perkuliahan menggunakan beberapa tahapan yaitu tahap pengujian integrasi, pengujian sistem, pengujian validasi dan pengujian penerimaan pada handphone. Pada aplikasi ini digunakan database MySQL untuk penyimpanan data-data jadwal perkuliahan, dan pembuatan aplikasi ini dibuat menggunakan PHP [14].

2. Mansur Membuat perancangan sistem informasi penjadwalan resource Perguruan Tinggi menggunakan metode Particle Swarm Optimization (PSO). Hasil dari informasi tersebut dapat membantu perguruan tinggi dalam merencanakan penggunaan ruangan, dan melakukan pengembangan program studi pada Politeknik Negeri Bengkalis. Tujuan penelitian ini adalah membuat sistem informasi penjadwalan kuliah untuk pemanfaatan resource pada perguruan tinggi menggunakan particle swarm optimization. Data resource dan constraint diimplementasikan menggunakan sistem informasi penjadwalan dengan pendekatan algoritma PSO [10].

3. Muhamad Taufik Hidayat Membuat rancangan perangkat lunak penjadwalan perkuliahan di Jurusan Teknik Industri Itenas. Pada penelitian ini dirancang suatu perangkat lunak aplikasi penjadwalan perkuliahan yang mampu mempermudah dan mempercepat proses penyusunan jadwal kuliah. Perancangan perangkat lunak dimulai dengan pemodelan yang dirancang kemudian dimodelkan ke dalam diagram-diagram yang terdapat di dalam metode UML (Unified Modeling Language) dan diimplementasikan menggunakan software Visual Basic 6.0. Dengan menggunakan aplikasi penjadwalan perkuliahan output jadwal yang dihasilkan bisa lebih cepat dan akurat [8].

4. Ginanjar Tegar Sanjaya Membuat rancang bangun Aplikasi Penjadwalan Kuliah STMIK AUB Surakarta Berbasis Web. Metodologi yang digunakan untuk merancang sistem penjadwalan adalah metode deskriptif menggunakan bahasa pemrograman PHP dan menggunakan MySQL sebagai pembuatan database . Sistem Aplikasi Penjadwalan ini dapat menjadwalkan hari ,dosen ,mata kuliah, ruangan , waktu perkuliahan dan kelas dari semua program studi tanpa bertabrakan bahkan pada dosen atau mahasiswa [13].

\subsection{Sistem}

Menurut Al-Bahra, "Sistem adalah sekelompok elemen yang terintegrasi dengan maksud yang sama untuk mencapai satu tujuan" [3]. Definisi lain dari Sistem menurut Jogiyanto Hartono dalam bukunya menjelaskan bahwa "Sistem adalah suatu jaringan kerja dari prosedur-prosedur yang saling berhubungan, berkumpul bersamasama untuk melakukan suatu kegiatan atau untuk menyelesaikan suatu sasaran tertentu" [6].

\subsection{Informasi}

Definisi Informasi menurut Jogiyanto dalam bukunya Analisis dan Desain menjelaskan bahwa "Informasi adalah data yang diolah menjadi bentuk yang lebih berguna dan berarti bagi yang menerimanya" [6]. Definisi lain dari Informasi menurut Supriyanto Aji dalam bukunya Pengantar Teknologi Informasi yang menyebutkan bahwa "Informasi adalah data yang telah diolah menjadi bentuk yang berarti bagi penerimanya dan bermanfaat dalam mengambil keputusan saat ini atau mendatang" [2]. Sumber dari informasi adalah data. Data adalah kenyataan yang menggambarkan suatu kejadian-kejadian dalam kesatuan nyata. Kejadian-kejadian (event) adalah sesuatu yang terjadi pada saat yang tertentu.

\subsection{Sistem Informasi}

Jika definisi sistem dan informasi disatukan menjadi sistem informasi, maka dapat didefinisikan sebagai suatu kegiatan 
dari prosedur-prosedur yang diorganisasikan, bilamana dieksekusi akan menyediakan informasi untuk mendukung pengambilan keputusan dan pengendalian di dalam organisasi. Lebih lanjut Abdul Kadir membedakan sistem informasi menjadi 2 bagian, yaitu sistem informasi manual dan sistem informasi berbasis komputer (computer based information system / CBIS). Dalam pembahasan selanjutnya, yang dimaksud dengan sistem informasi adalah jenis sistem informasi yang berbasis komputer [9].

\subsection{Monitoring}

Menurut KBBI (Kamus Besar Bahasa Indonesia), "Monitoring adalah alat yang dirancang untuk mengobservasi, mengawasi, mengontrol, atau memverifikasi operasi suatu system". Monitoring juga diartikan sebagai pengawasan dan tindakan memverifikasi kebenaran operasi suatu program selama pelaksanaannya berdasarkan rutin diagnostik yang digunakan dari waktu ke waktu untuk menjawab pertanyaan tentang program tersebut [12].

\subsection{WEB}

Menurut Gregorius Agung Website adalah "kumpulan halaman web yang saling terhubung dan file-filenya saling terkait. Web terdiri dari page atau halaman, dan kumpulan halaman yang dinamakan homepage. Homepage berada pada posisi teratas, dengan halaman-halaman terkait berada di bawahnya. Biasanya setiap halaman di bawah homepage disebut child page, yang berisi hyperlink ke halaman lain dalam web"[1]. Sedangkan Menurut Lukmanul Hakim, Website merupakan "fasilitas internet yang menghubungkan dokumen dalam lingkup lokal maupun jarak jauh. Dokumen pada website disebut dengan web page dan link dalam website memungkinkan pengguna bisa berpindah dari satu page ke page lain (hyper text), baik diantara page yang disimpan dalam server yang sama maupun server diseluruh dunia. Pages diakses dan dibaca melalui browser seperti Netscape Navigator, Internet Explorer, Mozila Firefox, Google Chrome dan aplikasi browser lainnya" [5].

\subsection{MySQL}

Menurut M. Rudianto Arief, "MySQL adalah salah satu jenis database server yang sangat terkenal dan banyak digunakan untuk membangun aplikasi web yang menggunakan database sebagai sumber dan pengolahan datanya" [4]. MySQL dikembangkan oleh perusahaan swedia bernama MySQL AB yang pada saat ini bernama Tcx DataKonsult AB sekitar tahun 1994-1995, namun cikal bakal kodenya sudah ada sejak tahun 1979. Awalnya Tcx merupakan perusahaan pengembang software dan konsultan database, dan saat ini MySQL sudah diambil alih oleh Oracle Corp.

\subsection{PHP (Personal Home Page)}

Menurut M. Rudianto Arief "PHP adalah Bahasa serverside -scripting yang menyatu dengan HTML untuk membuat halaman web yang dinamis. Karena PHP merupakan server- side-scripting maka sintaks dan perintah-perintah PHP akan diesksekusi diserver kemudian hasilnya akan dikirimkan ke browser dengan format HTML. Dengan demikian kode program yang ditulis dalam $\underline{\text { PHP }}$ tidak akan terlihat oleh user sehingga keamanan halaman web lebih terjamin. PHP dirancang untuk membuat halaman web yang dinamis, yaitu halaman web yang dapat membentuk suatu tampilan berdasarkan permintaan terkini, seperti menampilkan isi basis data ke halaman web" [4]. Sedangkan menurut Adi Nugroho "PHP atau singkatan dari Personal Home Page merupakan bahasa skrip yang tertanam dalam HTML untuk dieksekusi bersifat server side" [11]. PHP termasuk dalam open source product, sehingga source code $\underline{P H P}$ dapat diubah dan didistribusikan secara bebas.

\subsection{XAMPP}

XAMPP singkatan dari aplikasi dalam bundelnya, yaitu: $\mathrm{X}$ (berarti cross-platform, maksudnya tersedia dalam berbagai sistem operasi), Apache HTTP Server, MySQL, PHP dan Perl. Dengan mengisntall XAMPP, secara tidak langsung kita telah menginstall empat aplikasi tersebut.

\section{METODE PENELITIAN}

\subsection{Lokasi Penelitian}

Penelitian ini dilaksanakan di Fakultas Teknik Universitas Semarang, Penetapan lokasi penelitian ini didasarkan pada pertimbangan akses data lebih mudah karena lokasi penelitian berada pada lingkup kerja peneliti kemudian proses implementasi dan evaluasi sistem relatif lebih mudah dilakukan.

\subsection{Variabel Yang Diukur Atau Diamati}

Cakupannya meliputi perencanaan perkuliahan, pelaksanaan perkuliahan, evaluasi pelaksanaan perkuliahan, pengendalian pelaksanaan perkuliahan dan perbaikan perencanaan perkuliahan.

\subsection{Model Yang Digunakan}

Pada penelitian ini model aplikasi Sistem Informasi dan Monitoring Perkuliahan Fakultas Teknik Universitas Semarang Menggunakan metode dynamic priorities yang mendahulukan proses yang memiliki prioritas tertinggi serta mampu menanggapi perubahan lingkungan sistem saat beroperasi. Pemodelan sistem menggunakan paket XAMPP yang didalamnya terintegrasi modul PHP MyAdmin untuk keperluan basis data, PHP versi 7.0.2 untuk pengelolaan sistem informasi, dan Apache 2.4.18 untuk keperluan simulasi. Untuk pengkodean program aplikasi Notepad++ yang terintegrasi dalam sistem operasi windows, sedangkan untuk menjalankan aplikasi dan keperluan pengujian sistem digunakan web browser google chrome serta Mozilla Firefox. 


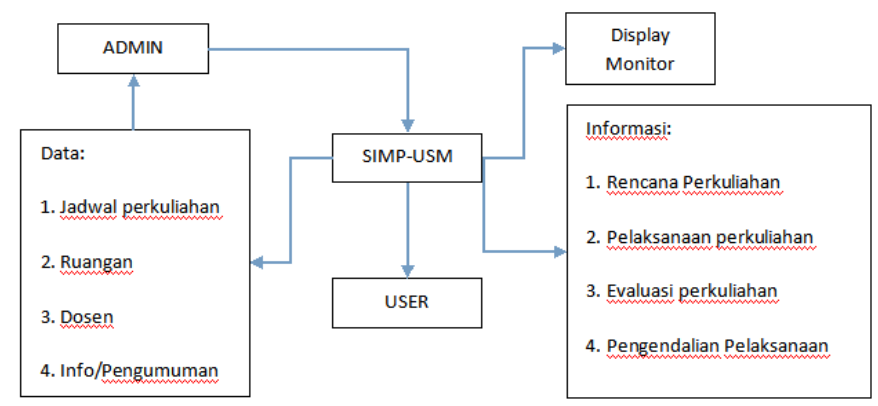

Gambar 3.1. Model Sistem Informasi Monitoring Perkuliahan

\subsection{Rancangan Penelitian}

Tahapan desain meliputi desain basis data, desain proses sistem, desain arsitektur sistem dan desain sistem informasi perkuliahan. Basis data yang dipakai pada penelitian ini dirancang dengan menggunakan aplikasi MySQL dan PHP MyAdmin untuk mengelola basis data. Setelah basis datanya selesai dibuat, maka langkah selanjutnya adalah merancang sistem informasi yang meliputi desain antar muka pemakai (user interface), desain pengelolaan data (input/edit database), desain keluaran (output), serta pemrograman WEB.

Untuk proses masukan ke database diklasifikasi menurut hak akses yang dimiliki oleh pengguna sistem terhadap basis data, yaitu akses User, Administrator, dan Super Administrator. User hanya memiliki akses mendapatkan informasi ataupun fungsi-fungsi lainnya yang disediakan dalam sistem informasi dan tidak memiliki akses untuk mengelola basis data. Administrator adalah Dosen atau Staf Admin yang memiliki akses untuk memasukkan atau merubah data hasil pengamatan ke dalam basis data. Sedangkan Super Administrator memiliki semua fasilitas yang dimiliki oleh seorang Administrator serta mampu menambah atau merubah status seorang administrator yang terdapat dalam basis data. Setelah data masukan dan keluaran selesai dirancang, kemudian dengan menggunakan aplikasi notepad++ dilakukan penulisan source code HTML + PHP + javascript untuk website. Proses pengujian sistem akan dilakukan secara offline melalui localhost yang merujuk pada alamat komputer sendiri.

\subsection{Tahapan Pembuatan SIMP}

Tahapan yang diperlukan dalam pembuatan suatu program SIMP-USM yaitu menganalisa sistem yang telah ada, dimana analisa sistem merupakan proses mempelajari suatu sistem dengan cara menguraikan sistem tersebut kedalam elemen yang membentuknya. Selanjutnya mengidentifikasi dan mengevaluasi permasalahan - permasalahan yang terjadi serta kebutuhan yang di perlukan, sehingga dapat di susulkan pembuatannya

Analisis sistem yang sedang berjalan di Fakultas Teknik Universitas Semarang terdiri dari flowmap, diagram konteks, dan DFD. Analisis sistem dalam suatu organisasi sangat penting karena fungsi dari analisis itu sendiri yaitu untuk mengetahui bagaimana sebuah sistem itu berjalan agar sistem yang dibuat itu menghasilkan output yang diinginkan dan dapat mencapai tujuan yang direncanakan.

\subsubsection{Flowmap}

Dari deskripsi prosedur sistem penjadwalan matakuliah yang sedang berjalan, maka akan terlihat secara lebih jelas prosedur penjadwalan matakuliah pada gambar 3.3. di bawah ini :

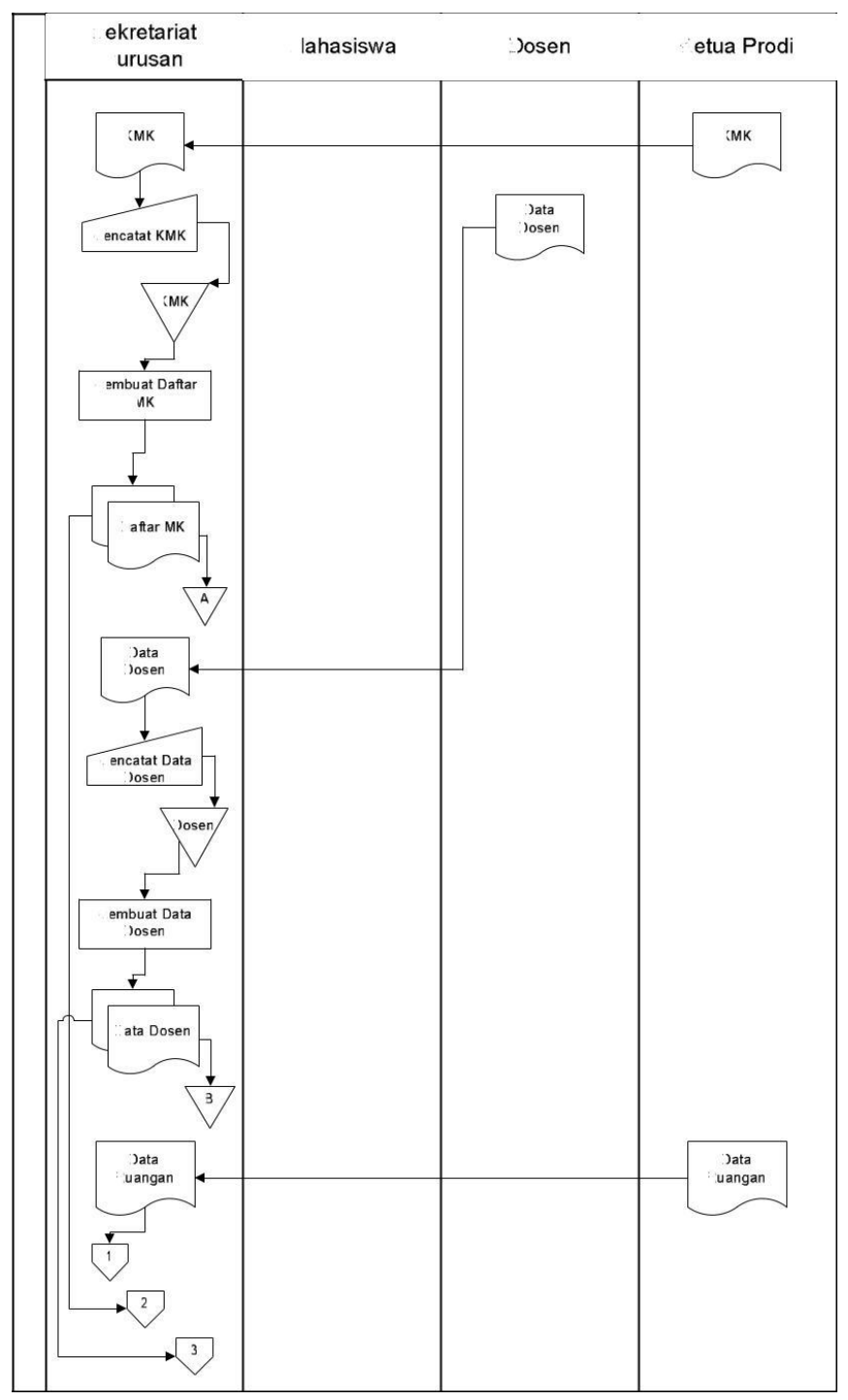




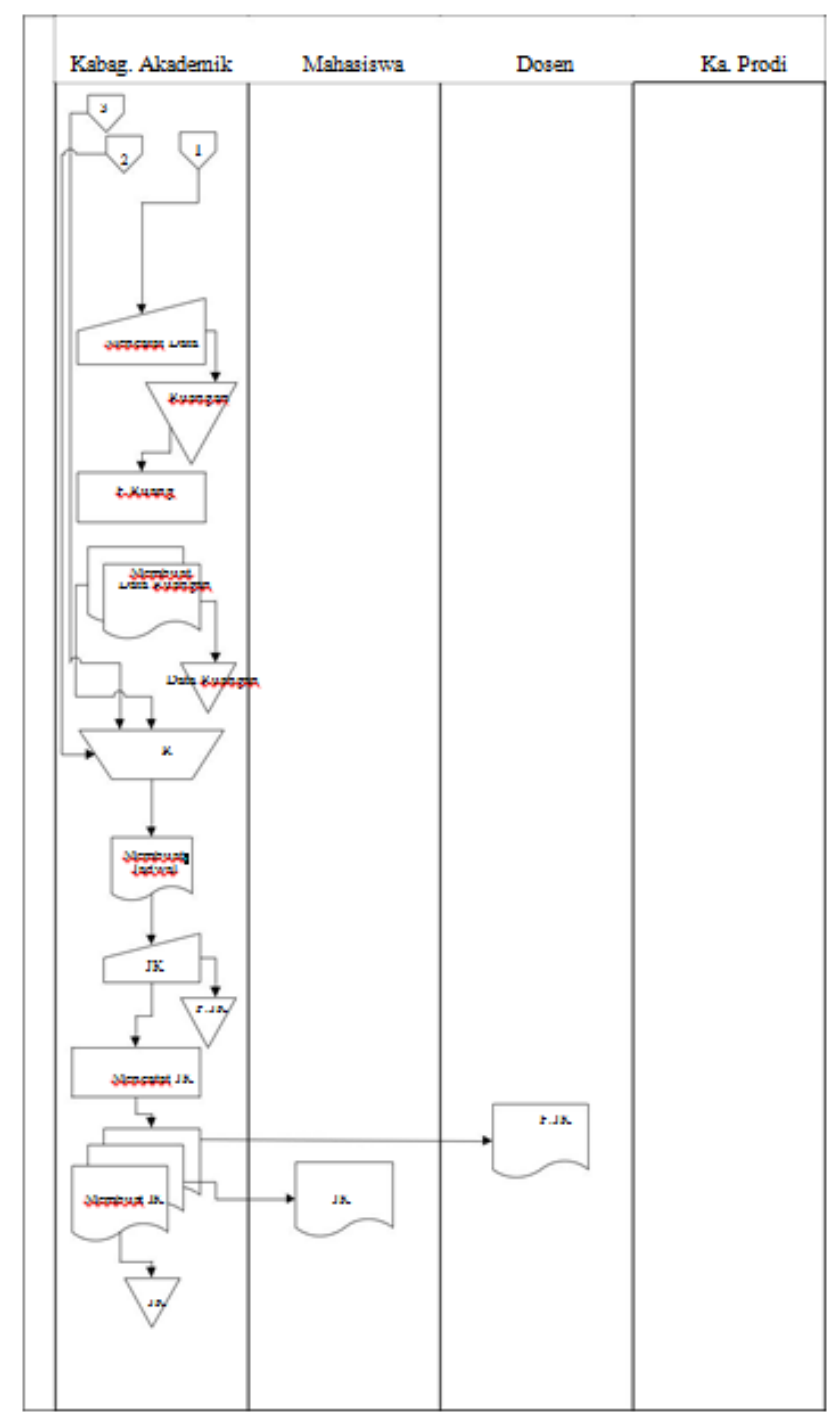

Gambar 3.2 Flow Map Sistem Informasi Penjadwalan yang Sedang Berjalan

\subsubsection{Diagram Konteks}

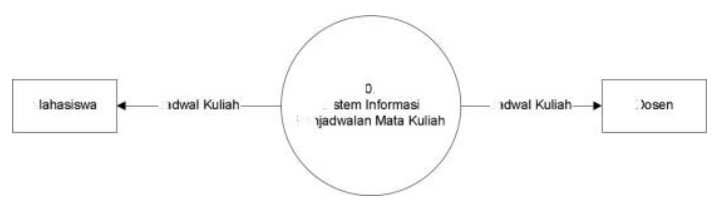

Gambar 3.3 Diagram Konteks Sistem Informasi Penjadwalan Mata Kuliah yang Diusulkan

\subsubsection{Data Flow Diagram (DFD)}

Data Flow Diagram merupakan diagram alir yang dipresentasikan dengan lambang-lambang tertentu. Dengan adanya DFD maka penulisan suatu program akan menjadi lebih mudah dalam pelaksanaannya, karena menggunakan lambanglambang yang bersifat standar yang ditetapkan secara umum dalam penulisan desain. Penulisan DFD ini bertujuan untuk menggambarkan sistem yang sedang berjalan. Berikut ini adalah DFD pada Sistem Informasi Penjadwalan yang diusulkan di Fakultas Teknik USM :

1. DFD Level 1 Sistem Informasi Penjadwalan Matakuliah

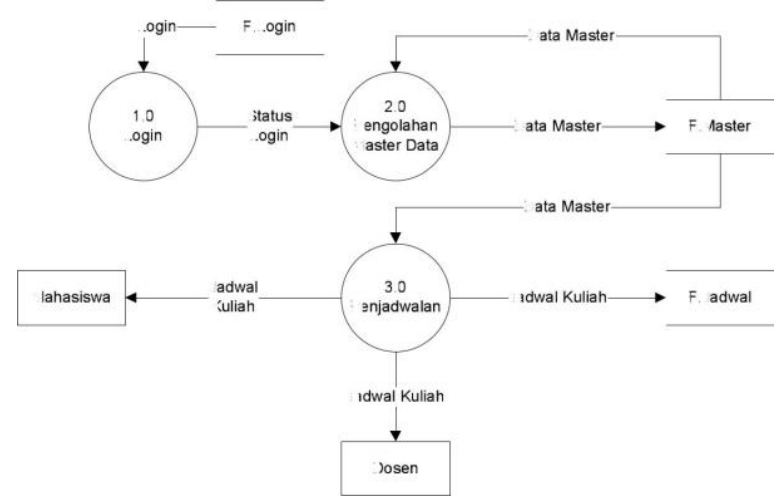

Gambar 3.4 DFD Level 1 Sistem Informasi Penjadwalan Mata Kuliah yang Diusulkan

2. DFD Level 2 Proses 2.0 Pengolahan Master Data yang diusulkan

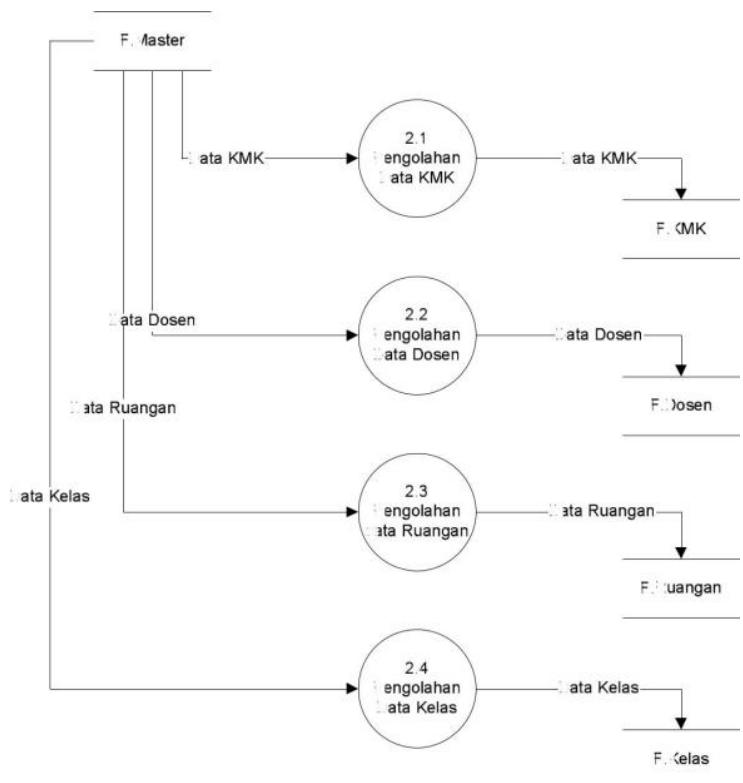

Gambar 3.5 DFD Level 2 Proses 2.0 Pengolahan Master Data yang Diusulkan 
3. DFD Level 2 Proses 3.0 Penjadwalan

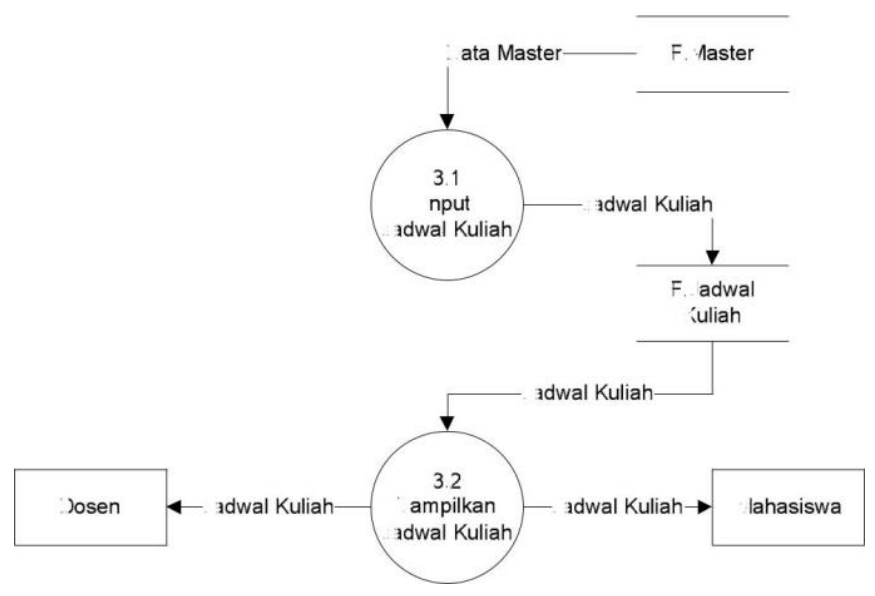

Gambar 3.6 DFD Level 2 Proses 3.0 Penjadwalan yang Diusulkan

4. DFD Level 3 Proses 2.1 Pengolahan Data KMK (Kurikulum Mata Kuliah)

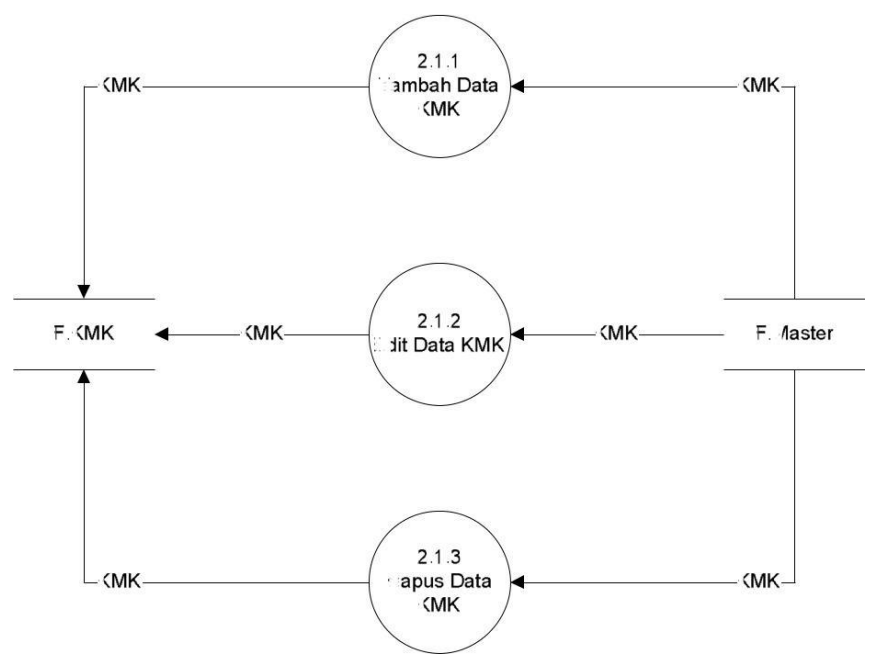

Gambar 3.7 DFD Level 3 Proses 2.1 Pengolahan Data KMK
5. DFD Level 3 Proses 2.2 Pengolahan Data Dosen

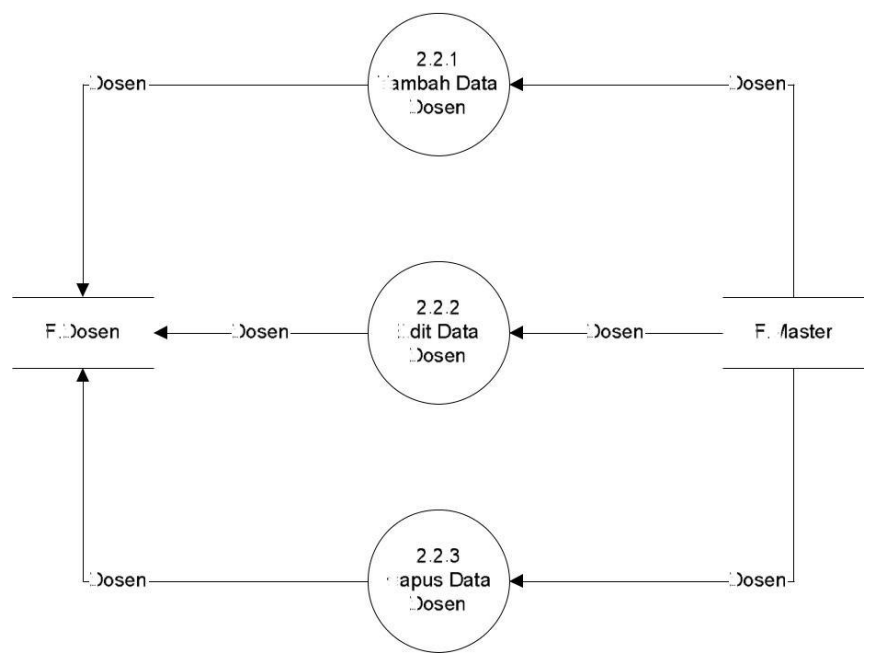

Gambar 3.8 DFD Level 3 Proses 2.2 Pengolahan Data Dosen

6. DFD Level 3 Proses 2.3 Pengolahan Data Ruang

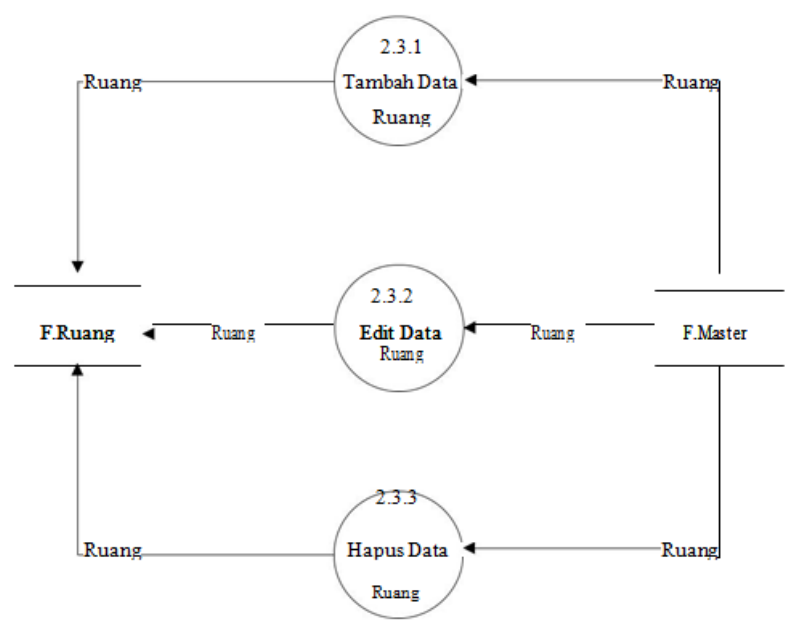

Gambar 3.9 DFD Level 3 Proses 2.3 Pengolahan Data Ruang 
7. DFD Level 3 Proses 2.4 Pengolahan Data Kelas

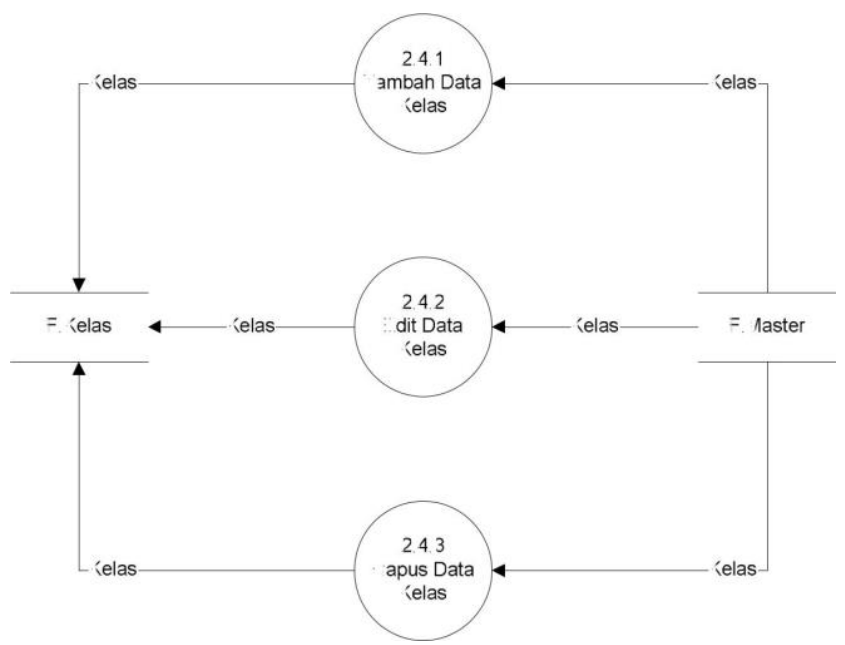

Gambar 3.10 DFD Level 2 Proses 2.4 Pengolahan Data Kelas

8. DFD Level 3 Proses 3.2 Tampilkan Jadwal Kuliah

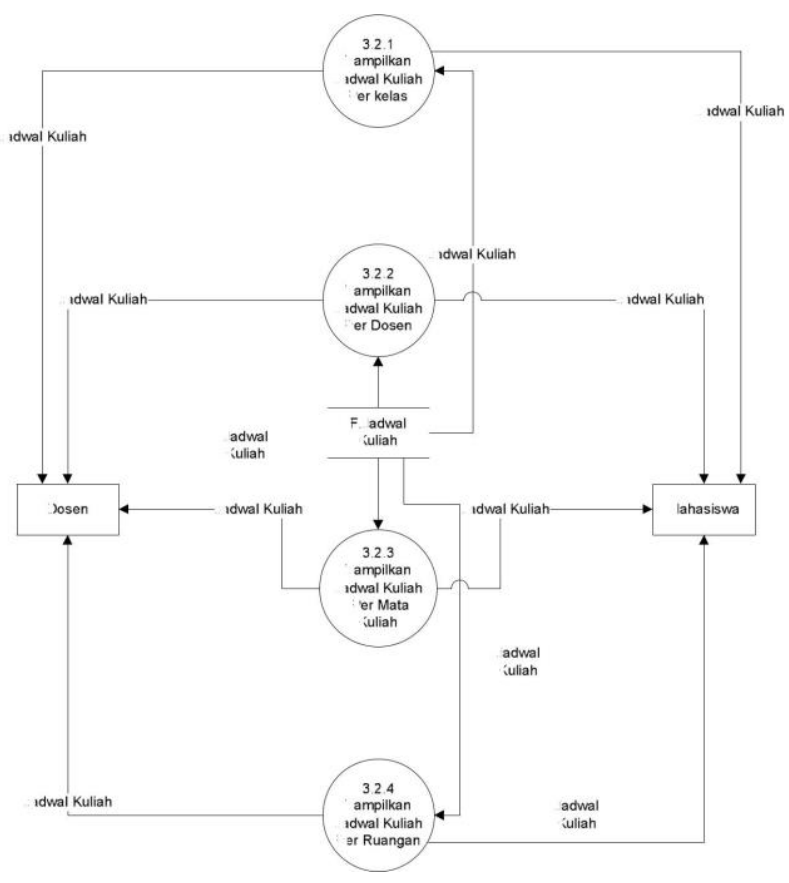

Gambar 3.11 DFD Level 3 Proses 3.2 Tampilkan Jadwal Kuliah

\section{HASIL PENELITIAN DAN PEMBAHASAN}

\subsection{Input Data SIMP}

Tahapan pengisian data SIMP-USM terdiri dari pengisian data mata kuliah, data dosen, data ruangan, Jadwal mata kuliah serta informasi atau pengumuman. Gambar 4.1 menunjukan tampilan awal dari SIMP setelah proses login berhasil dilakukan dengan cara memasukan nama user dan password. Maka akan tampil homepage seperti gambar berikut ini.

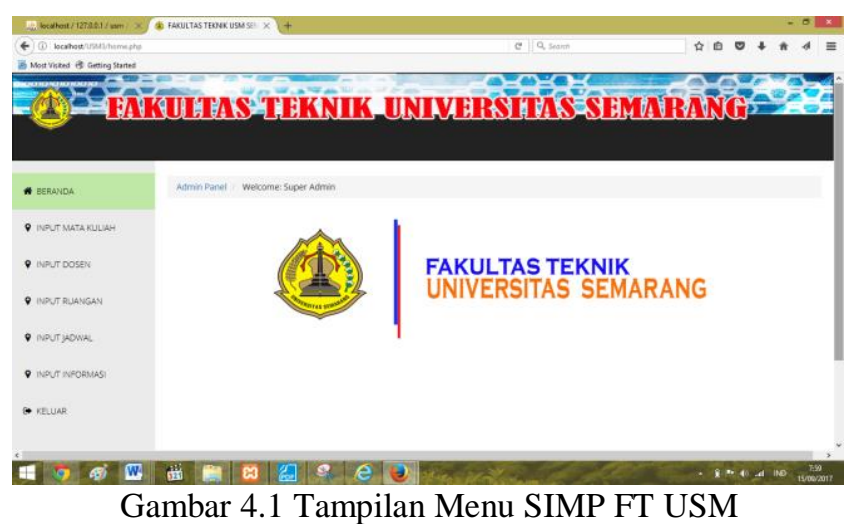

\subsection{Pengujian Sistem}

Implementasi pengujian SIMP-FT USM berbasis Web telah dilaksanakan secara offline pada hari Senin, tanggal 28 Agustus 2017 bertempat di ruang lobby gedung A Fakultas Teknik Universitas Semarang. Pengujian secara offline dilakukan karena fakultas teknik belum memiliki alamat domain URL sendiri sehingga pengujian secara online belum bisa dilakukan. Dari hasil pengujian dapat dilihat bahwa sistem yang telah dibuat bekerja dengan baik.

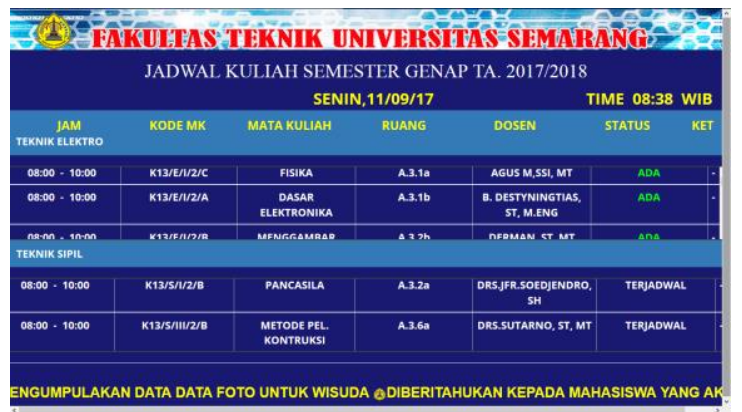

Gambar 4.2. Tampilan Jadwal Kuliahp SIMP FT-USM

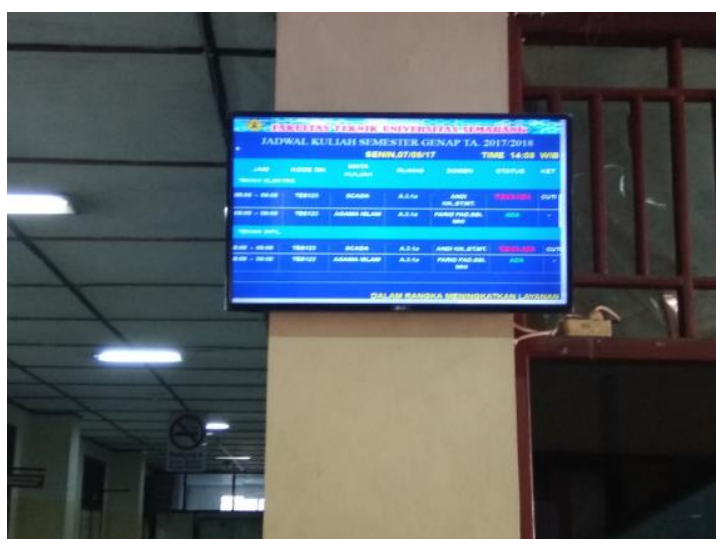

Gambar 4.3 Tampilan Layar Utama SIMP FT-USM 


\section{PENUTUP}

[7] Hartono, Jogiyanto. "Pengenalan Komputer".

\subsection{Kesimpulan}

Aplikasi Sistem Informasi Monitoring Perkuliahan Fakultas Teknik Universitas Semarang (SIMP-USM) yang cakupannya meliputi perencanaan perkuliahan, pelaksanaan perkuliahan, evaluasi pelaksanaan perkuliahan, pengendalian pelaksanaan perkuliahan dan perbaikan perencanaan perkuliahan.

\subsection{Saran}

Dalam rangka mengimplementasikan Sistem Informasi Monitoring Perkuliahan (SIMP) pada Fakultas Teknik Universitas Semarang peneliti menyarankan :

1. Diperlukan server sendiri. Oleh karena itu, peneliti menyarankan kepada pihak Fakultas agar menyediakan peralatan penunjang untuk pembuatan server yang bertujuan untuk peningkatkan traffic data bagi pengguna yang akan mengakses SIMP-USM dapat berjalan secara maksimal.

2. Serta perlu diadakannya pelatihan teknis pengisian jadwal kuliah bagi tenaga admin yang akan mengelola SIMP FTUSM ini.

\section{UCAPAN TERIMA KASIH}

Penulis mengucapkan terima kasih kepada DIPA Direktorat Riset dan Pengabdian Kepada Masyarakat (DRPM) Kementerian Riset, Teknologi dan Pendidikan Tinggi atas biaya penelitian yang telah diberikan.

\section{DAFTAR PUSTAKA}

[1] Agung, Gregorius. "Membuat Homepage Interaktif Dengan CGI-Perl”. Jakarta: PT. Elex Media Koputindo. 2000.

[2] Supriyanto, Aji. "Pengantar Teknologi Informasi". Jakarta: Salemba Infotek. 2005.

[3] Al-Bahra bin Ladjamudin. "Analisis dan Desain Sistem Informasi”. Yogyakarta : Graha Ilmu. 2005.

[4] Arief, M.Rudianto. "Pemrograman Web Dinamis Menggunakan PHP dan MySQL". Yogyakarta: Andi. 2011.

[5] Hakim, Lukmanul. "Cara Cerdas Menguasai Layout, Desain dan Aplikasi Web". PT. Elekx Media Komputindo: Jakarta. 2004.

[6] Hartono, Jogiyanto. Sistem Teknologi Informasi. Edisi II. Yogyakarta: Andi Offset. 2005.
[8] Hidayat, Muhamad Taufik. "Rancangan Perangkat Lunak Penjadwalan Perkuliahan di Jurusan Teknik Industri ITENAS". Jurnal Online Institut Teknologi Nasional No.011Vol.01. ISSN: 2338-5081. Januari 2014

[9] Kadir, Abdul. "Dasar Pemrograman WEB Dinamis menggunakan PHP”. Yogyakarta: Andi. 2002.

[10] Mansur. 'Perancangan Sistem Informasi Penjadwalan Resource Perguruan Tinggi Menggunakan Metode Particle Swarm Optimization (PSO)". Inovtek, Volume 4 No. 2, halaman. 75 - 86. Oktober 2014,

[11] Nugroho, Adi. "E-commerce". Informatika Bandung. Bandung. 2006.

[12] Pusat Pembinaan dan Pengembangan Bahasa (P3B), Departemen Pendidikan dan Kebudayaan. "Kamus Besar Bahasa Indonesia”. Jakarta.1983

[13] Sanjaya, Ginanjar Tegar. "Rancang Bangun Aplikasi Penjadwalan Kuliah STMIK A UB Surakarta Berbasis Web". Jurnal Ilmiah Go Infotech Volume 21 No. 1, Juni 2015 ISSN : 1693-590x. 2015.

[14] Usada, Elisa. "Rancang Bangun Sistem Informasi Jadwal Perkuliahan Berbasis Jquery Mobile Dengan Menggunakan PHP dan MySQL". Jurnal INFOTEL (Informatika, Telekomunikasi \& Elektronika) Vol 4 No.2. pISSN:2085-3688. 2012 